\title{
SUSTAINABLE INDUSTRIAL DESIGN WITH ERGONOMICS FOR STREET A SWEEPING MACHINE
}

\author{
Adebesin, A.A. \\ Department of Mechanical Engineering \\ The Federal Polyechnic, Ilaro, \\ Ogun State, Nigeria.
}

\begin{abstract}
Sweeping using hand- held broom and parker is a traditional method that is laborious and painstaking with its associated spinal and waist disorders. Wastes may be solid e.g. domestic, commercial and industrial: (plastics, containers, bottles, cans, papers, scrap iron, and other trash), liquid e.g. domestic washings, chemicals, oils, waste water from ponds, manufacturing industries and all other sources. Street sweeping machines are designed to either sweep, pick or vacuum wastes which are substances or objects disposed off or are intended to be disposed off or are required to be disposed off by the provisions of the law but its ergonomic design entails the analysis of the product and the determination of the manufacturing operations and facilities required to produce it to specifications as economically as possible. Ergonomic is a veritable tool that comes into play when it is required to design the manufacturing process for a given component such that the reliability of that engineering systems has become an important issue during the design process because of the increasing dependence of our daily lives and schedules on the satisfactory functioning of these systems. The ergonomics of their design must be a subject of concern to the designer considering its users friendliness.
\end{abstract}

Keywords: Ergonomics, Street sweeping, Machine, Sustainable, Wastes, Industrial

\section{INTRODUCTION}

The phenomenon of street littering has been on the increase to the extent that it is becoming a concern to all and sundry, [Aluko, 2001]. Recently, evidences have shown that the increase in the incidences of street littering with waste could be linked to some reasons. These include increasing urbanization, industrialization, and population. Booming economic activities, unavailability of portable machine to sweep the street, human attitudes towards a clean and safe environment, cultural issues, and indiscriminate

\author{
Adedeji, K.A \\ Department of Mechanical Engineering, \\ Lagos State University, Epe Campus, Lagos \\ State, Nigeria
}

disposal of wastes along road medians / margins are also contributing factors. Knowledge of draught and sweeping head requirement of mechanical street sweeping equipment for proper design of the sweeping machine, appropriate matching of the head with its full assembly and the selection of optimum operation conditions [Ademosun,1990]. Sweeping has been a very essential part of housekeeping. Sweeping is an age long practice of cleaning garbage, refuse, dirt, dust, rubbish and unwanted materials away from our environments so as to make our, immediate environment attractive and adorning to look and to prevent diseases, [Aroboinnosen, 2009]. Every home has some sort of broom or other sweeping products that are used to clean up our houses, backyards, farms and just almost any place. It is interestingly to know that the various kinds of brooms that we are using today evolved from something that has been here for a really long time, long or short brooms were usually used to sweep rooms, passages, corridors and streets but recently, the culture of housekeeping has been extended to our major roads and streets with the advent of street sweeping machines. These street sweeping machines were fabricated in the $19^{\text {th }}$ century to sweep corridors and streets more efficiently but today, modern street sweepers are attached on truck bodies and can sweep and vacuum debris that accumulates in streets, they are capable of collecting small particles of debris and particulate matter of $10 \mu \mathrm{m}$ or less. Despite technological advancements in the number of street sweeping machines being produced, the mechanical broom type street sweeper accounts for approximately $90 \%$ of all street sweepers used in the United States today.

Sustainable Design: The continuing cry of highway manager is for ways of reducing costs, to offset the ever increasing demands they must pay for labor and materials like brooms, parkers etc. and this particular street sweeping design concept is their prime sources of cost-improvement opportunities in terms of designing and fabrication of the component parts locally. [Adebesin,2017]. Industrial design, according 


\section{International Journal of Engineering Applied Sciences and Technology, 2020 \\ Vol. 5, Issue 2, ISSN No. 2455-2143, Pages 119-126 \\ Published Online June 2020 in IJEAST (http://www.ijeast.com)}

to [Adepoju, 1990] is a procedure for identifying the operations required to produce a product or its components so as to achieve the desired production objectives. Process design work is frequency thought of as dealing only with the careful and detailed process of production. [Daniel 1985]

Design Concept: This has to do with the classification of fabrication processes by type or by equipment utilized for the production. A unit process is a modification of material done essentially without interruption i.e. the unit process does not tell which machine is to be used to modify material, it only indicate what the modification will consist of. The unit process concept has several advantages:

1. Unit processes are convenient in describing what is to be done to material to modify it.

2. Unit processes offer a convenient basis for organizing detailed process information
3. Unit processes make it easier to synthesize a new process

4. Unit processes make it easier to compare processes because cost characteristics can be conveniently compared.

\section{Human factor}

In the case of developing a street sweeping machine, where pushing constitutes a major means of driving the machine, it could be ascertained that the position of the body relative to the machine depend upon the interaction of the operator characteristics and task characteristics. To achieve the best possible match between the machine and its user (operator) the machine was designed in the context of the sweeping task, physical and mental characteristics of the user.

This conceptualized model depicts the hand held broom sweeping method and its associated discomfort as shown below

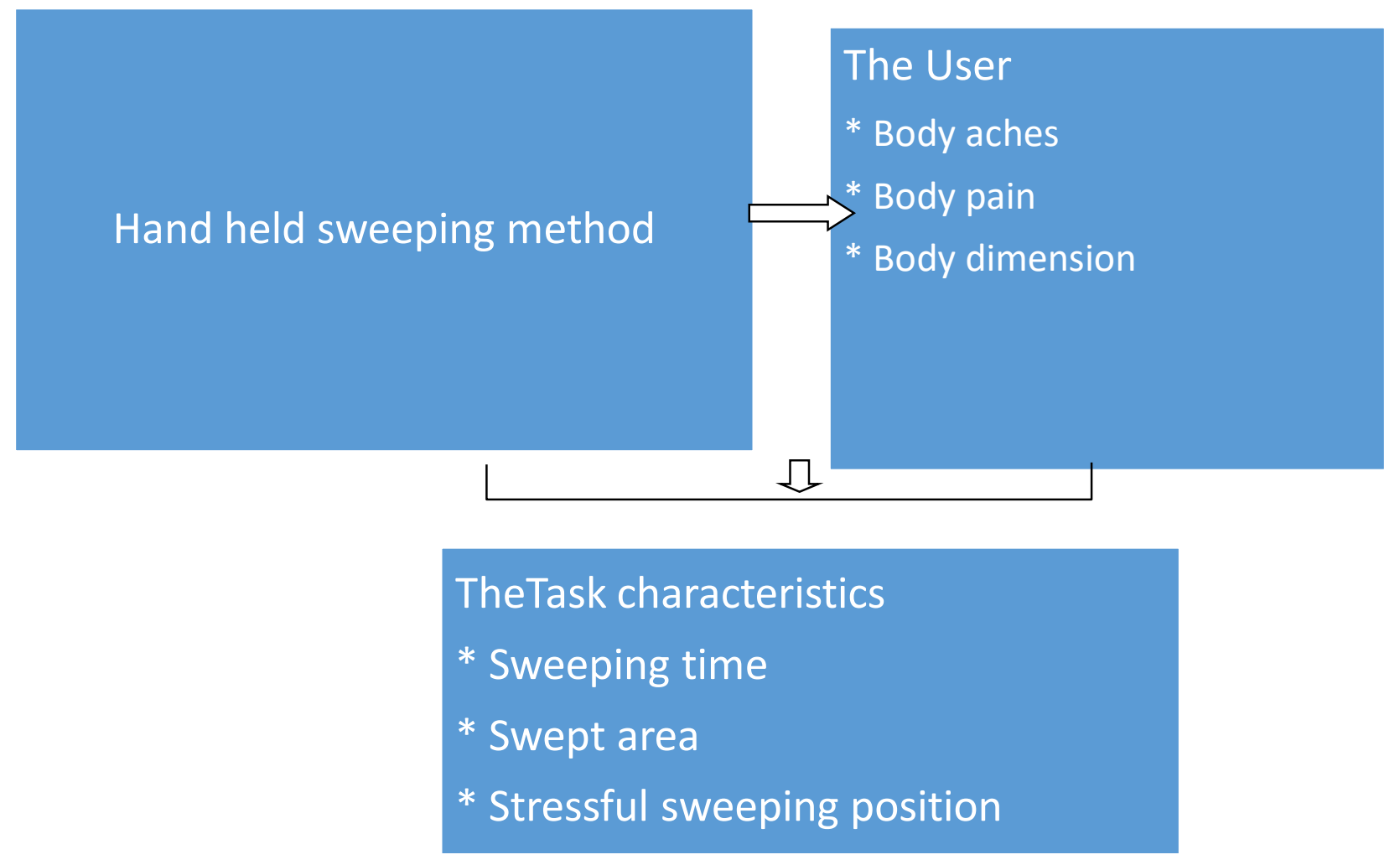

Figure 1: Hand held broom concept: The sweeping and the task characteristics.

\section{LITERATURE REVIEW}

\section{Ergonomics and Functional Requirements}

Ergonomics is the study of man at work. More precisely, it is the study of people in relation to the equipment they use in a specific environment while performing certain tasks. [Pheasant, 1986]. Anthropometric data simply means a collection of the dimensions of human body. The data is useful for apparel sizing, forensics, physical anthropometry and ergonomic design of any machine. [Bridger, 1995] 


\section{International Journal of Engineering Applied Sciences and Technology, 2020 Vol. 5, Issue 2, ISSN No. 2455-2143, Pages 119-126 \\ Published Online June 2020 in IJEAST (http://www.ijeast.com)}

The use of anthropometry in design may improve the health, comfort, well being and safety of the user of products [Pheasant, 1998].

Bending/Tilting Position: According to Troussier et al [1994], Sweepers find the sweeping position to be unpleasant and unhealthy. Continuous sweeping in the same posture in a forward bending position subjected the muscles, the ligaments and in particular the knees to some undesirable physiological strain.

[Zacharkow, 1988] opined that the side effects of bad sweeping position on the spine have been known for a long time and the sweeping dynamics can best be comprehended by studying the fundamental principles of mechanics for all the relevant body parts and the external support system involved.

According to Pheasant, 1998, he affirmed that about seventy five percent $(75 \%)$ of the total body weight is supported by only $26 \mathrm{~cm}^{2}$ of surface when sweeping. He then gave a vivid description of the spine in relax sitting and upright positions. He argued that the pelvis rotates backward and the spine is flexed when in the relaxed position. This backward rotation needed to be catered for by the equivalent degree of freedom in the lumbar spine if overall line of the trunk is to remain vertical; hence in sitting down human beings tend to flatten out the concavity of the lumbar region. We shall probably also need to activate our back muscle to support the push force of operating the sweeper and if prolonged, this static muscle loading may become a major source of postural discomfort, particularly in someone who has a pre - existing tendency to suffer from back trouble [Pheasant, 1998] Improper posture can cause stress to joints which if it is combined with weak muscles, can cause their wear and permanent damage.

\section{Anthropometrics}

The study of human body measurements is known as anthropometrics. The application of anthropometry cuts across many disciplines like anthropology, medicine, criminology military science, engineering and design with its application. Designers make use of anthropometry to measure body size. Also, measurement between landmarks are taken in various positions, which could be standing and sitting, height from the floor, assorted circumferences, body breadths and depth relative to the developed sweeping machine. Ismaila. [2009] affirmed that the forward reach measurements of an average man taken while standing ranges from $30.8 "-36.1$ " for females and 33.8" 39.5 " for males and based on this height consideration, the street sweeping machine was designed for human reach capability to a height of $35.4^{\prime \prime}(900 \mathrm{~mm})$ as this will help prevent body pains and backache which are characteristics of the traditional sweeping method.

\section{Hand and Wrist Problems}

The average hand grip of the operators was considered as this is an important factor. Hand dimensions such as the breadth of the hand, circumference of the hand and its maximum grip are considered. According to Das 2004, the hand and wrist stresses can take a variety of forms such as occupational repetitive microtrauma, cumulative trauma disorder, repetitive motion injury, overuse syndrome, repetitive strain injury, carpal tunnel syndrome and repetitive stress disorder. Repetitive motion hand disorders are predominantly caused by constant flexion and extension motions of the wrist and fingers. Harris, 2000 affirmed that chronic, repetitive movements of the hand and wrist, especially with the hand in "pinch" position, seem to be the most detrimental. Common contributing factors to hand and wrist injuries include working for too long a period without allowing rest or alternation of hand and forearm muscles; movements in which the wrist is deviated from natural posture into an abnormal or awkward position; mechanical stresses to digital nerves from sustained grasps to sharp edges on instrument handles; forceful work; and extended use of vibratory instruments.

According to OSHA (2000), work-related Municipal Solid Disposal (MSD) is a condition when the physical capabilities of the worker do not match the physical requirements of the job coupled with the prolonged exposure to ergonomic risk factors which can cause damage to a worker's body and lead to MSDs. Other factors that are likely to cause MSD problems include the following:

a. Excessive repetition of movements that can irritate tendons and increase pressure on nerves.

b. Awkward postures or unsupported positions that stretch physical limits can compress nerves and irritate tendons.

c. Exerting excessive force.

d. Static postures or positions that a worker must hold for long periods of time can restrict blood flow and damage muscles.

e. Motion, such as increased speed or acceleration when bending and twisting, can increase the amount of force exerted on the body.

f. Inadequate recovery time due to overtime and lack of break can leave insufficient time for tissue repair; frequently, workers must loose time from work to recover; while some never regain full health. 


\section{International Journal of Engineering Applied Sciences and Technology, 2020 \\ Vol. 5, Issue 2, ISSN No. 2455-2143, Pages 119-126 \\ Published Online June 2020 in IJEAST (http://www.ijeast.com)}

g. Vibrating tools because of excessive vibration, can decrease blood flow, damage nerves, and contribute to muscle fatigue.

h. Pushing street sweeping machine or operating subways with the whole body subjected to vibration, can affect skeletal muscles leading to low back pain.

\section{The Risk Factors}

These risk factors, whether alone or in combination, can subject workers' shoulders, hands, arms, wrists, backs, and legs to thousands of repetitive twisting, forceful, or flexing motions during a typical workday. To contribute to MSDs, however, these risk factors must be present for a sufficient duration, frequency, or magnitude (Balague et al, 1999).

Parts of the body affected by MSDs are: arms, back, hands, wrists, fingers, legs, neck and shoulders.

The symptoms of work-related MSDs include:

1. Numbness in thighs,

2. Stiffness in moving finger,
3. Numbness in fingers,

4. Back pain, or

5. Stiff joints

\section{MATERIALS AND METHODS}

Five anthropometric variables of 15 street sweeping machine operators, randomly selected from six urban centers (Abeokuta, Sango, Dugbe, Epe, Agbara and Akure) in four states (Ogun, Oyo, Lagos and Ondo states) in South -West Nigeria were collected as case study.

Measuring Instruments: A digital Stadiometer PD 300M (DETECTO); a large digital vernier caliper $600 \mathrm{~mm}$; a small digital vernier caliper $-150 \mathrm{~mm}$. a 3.5m Komelon Steel tape; and a Mitutoyo Universal Bevel Protractor; were used for this wok.

Collection of relevant anthropometric dimensions of the street sweepers

Table 1: Anthropometric parameters of street sweepers and their relevance

\begin{tabular}{|l|l|l|}
\hline Parameter Number & Parameter Name & Relevance \\
\hline$P_{1}$ & Shoulder to Elbow & Push \\
\hline$P_{2}$ & Back Angle & Tilting \\
\hline$P_{3}$ & Forward Push Foot Length & Walking \\
\hline$P_{4}$ & Ergonomic Distance & Height \\
\hline$P_{5}$ & Elbow to Wrist & Push \\
\hline
\end{tabular}

\section{Statistical Data Analysis}

The data for each of the anthropometric parameter data of different operators pushing the street sweeping machine was analyzed statistically by using SPSS 16.0 statistical package and Microsoft Excel (2007 program; descriptive and analytical statistics was generated. The anthropometric data was analyzed using means, standard deviations (SD) and $5^{\text {th }}, 50^{\text {th }}$ and $95^{\text {th }}$ percentiles. A typical biomechanical link-joint diagram (Fig. 2) representing a street sweeping machine operator was used to derive the two mathematical models; while Fig. 3 shows the relative placement of the two major controls (hands and legs) relative to the machine push.

\section{RESULTS AND DISCUSSION}

Table 2: Anthropometric data of different operators

\begin{tabular}{|l|l|l|l|l|l|}
\hline $\begin{array}{l}\text { Operator's } \\
\text { Dimension/ } \\
\text { Location }\end{array}$ & $\begin{array}{l}\text { Standing Knee } \\
\text { Height }\end{array}$ & $\begin{array}{l}\text { Shoulder } \\
\text { Height }\end{array}$ & $\begin{array}{l}\text { Leg } \\
\text { Clearance }\end{array}$ & $\begin{array}{l}\text { Fore Arm } \\
\text { Hand Length }\end{array}$ & $\begin{array}{l}\text { Hand to Hand } \\
\text { Distance }\end{array}$ \\
\hline Ogun & 90 & 87 & 45 & 65 & 34 \\
\hline Oyo & 85 & 88 & 42 & 64 & 33 \\
\hline Lagos & 87 & 85 & 43 & 65 & 34 \\
\hline Ondo & 88 & 86 & 44 & 65 & 34 \\
\hline
\end{tabular}




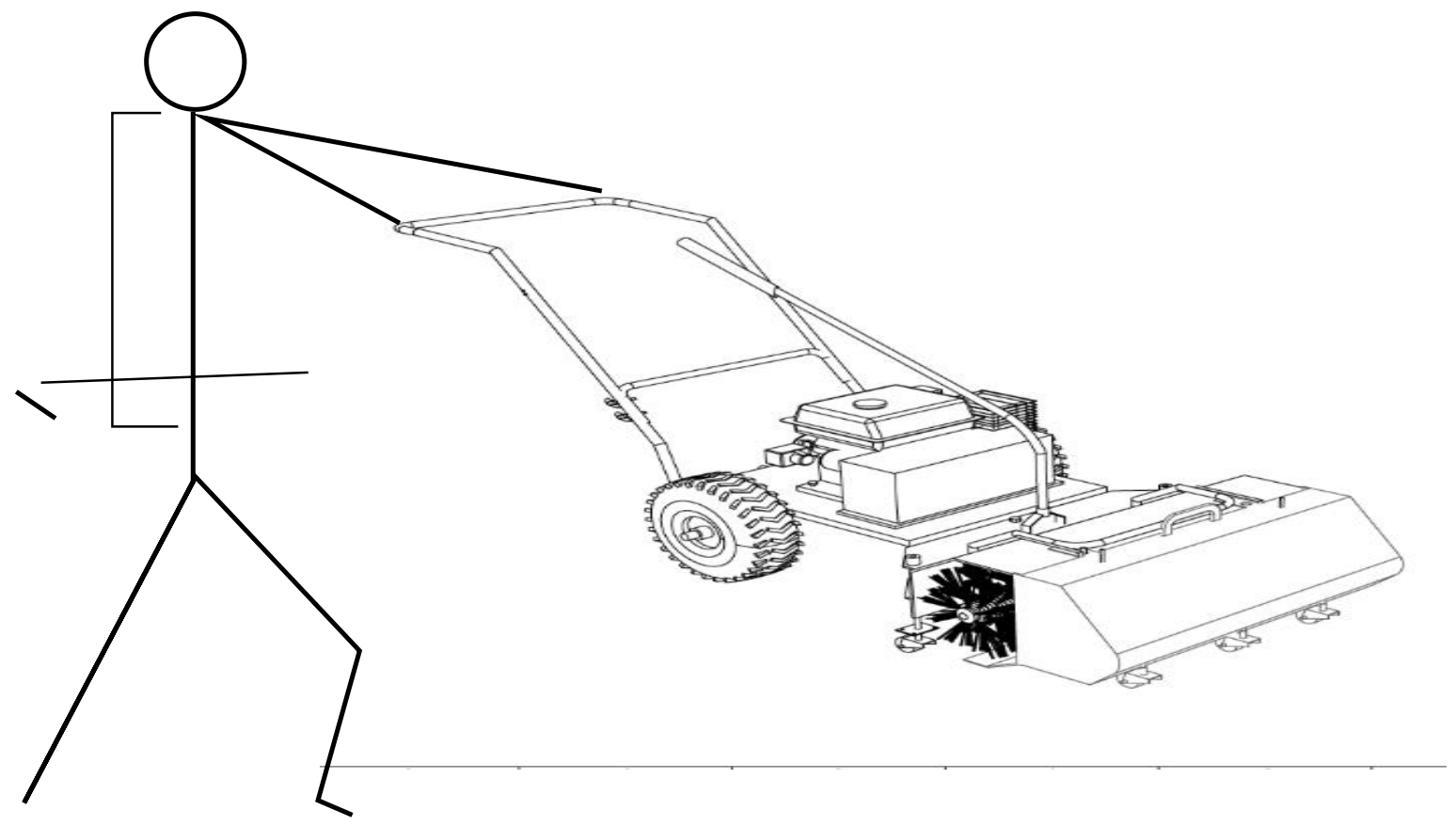

Figure 2: A biomechanical link joint/Assembly Drawing of the Machine

\section{Safety Design}

Safety in the overall design of the sweeper is a major consideration. Furthermore, the overall sweeping machine developed employs the concept of 'safety through design, which is the integration of hazard analysis and risk assessment methods in the design and fabrication stages, so that the risk of injury or damage is at an acceptable level. Thus, this concept is based on the principles of avoiding, reducing the probability of a hazard related incident occurring; minimizing damage should an incident occur which is most effectively performed when designing new equipment.

Table 3: List of Components and Material Type for

A Street Sweeping Machine

\begin{tabular}{|c|l|l|}
\hline S/N & COMPONENT NAME / DESCRIPTION & MATERIAL TYPE \\
\hline 1 & Waste collection bucket & Mild Steel \\
\hline 2 & Gear box & Cast \\
\hline 3 & Engine Shaft & Mild Steel \\
\hline 4 & Bearings & Mild Steel \\
\hline 5 & Chain Guide & Cast \\
\hline 6 & Bucket Hanger & Mild Steel \\
\hline 7 & Castor Tyre & Rubber \\
\hline 8 & Steering Lever & Mild Steel \\
\hline 9 & Engine Seat & Mild Steel \\
\hline 10 & Shaft & Mild Steel \\
\hline
\end{tabular}


International Journal of Engineering Applied Sciences and Technology, 2020

Vol. 5, Issue 2, ISSN No. 2455-2143, Pages 119-126

Published Online June 2020 in IJEAST (http://www.ijeast.com)

\begin{tabular}{|c|l|l|}
\hline 11 & Sweeping Brush & Teflon \\
\hline 12 & Teflon Drum & Teflon \\
\hline 13 & 7.5 H.P Gasoline Engine & Cast / Mild Steel \\
\hline 14 & Gripper Guide Fork & Mild Steel \\
\hline 15 & Guide Roller & Mild Steel \\
\hline 16 & Bush & Mild Steel \\
\hline 17 & Spacer & Mild Steel \\
\hline 18 & Guide Bush & Mild Steel \\
\hline 19 & Guide Pin Bush & Mild Steel \\
\hline 20 & Spacer & Mild Steel \\
\hline 21 & Spring & Stainless \\
\hline 22 & O - Ring & Mild Steel \\
\hline 23 & Hex. Bolt & Mild Steel \\
\hline
\end{tabular}

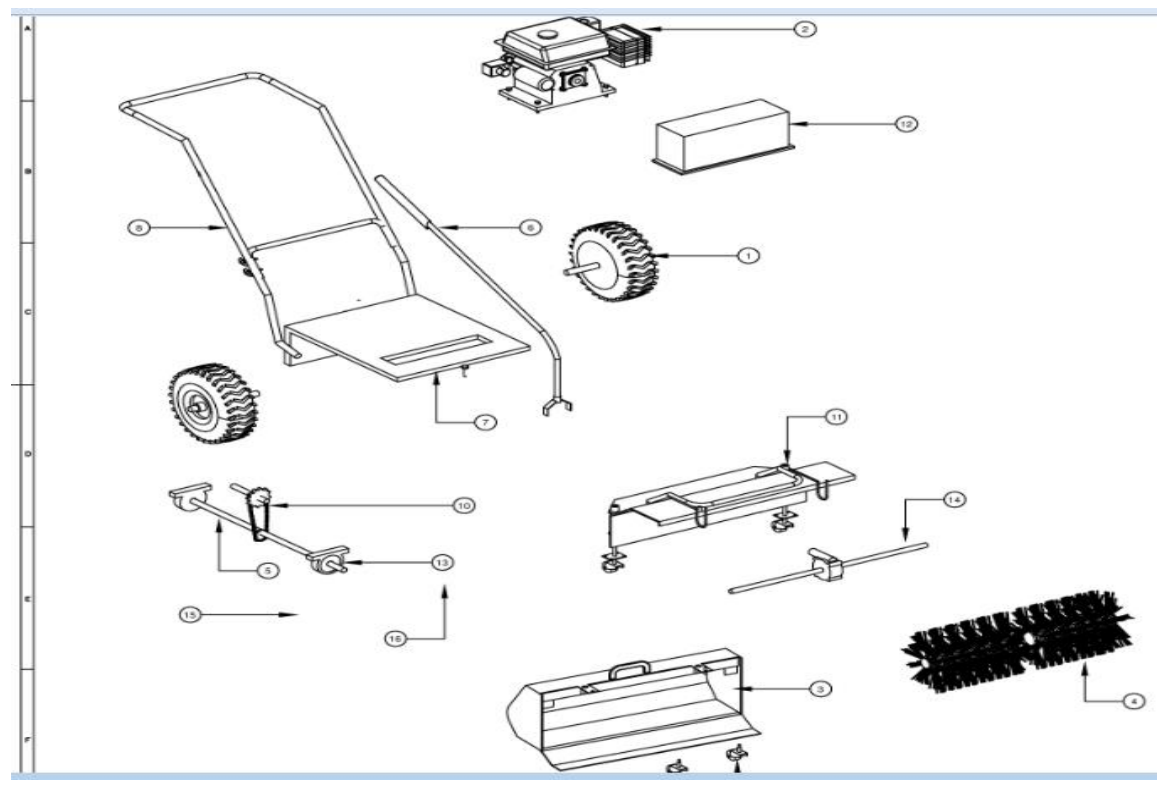

Figure 3: Exploded Drawing of the Machine

\section{CONCLUSION}

The following conclusions follow this study.

1. Mechanical sweeping machine for waste remover has been designed, fabricated and assembled for cleaning public places. Health, comfort, wellbeing and safety of the operator as considered could be likened to the ergonomic design work of Pheasant 1998.

2. The machine was developed from locally sourced materials as this served as alternative to handheld broom and parker method. 


\section{International Journal of Engineering Applied Sciences and Technology, 2020 \\ Vol. 5, Issue 2, ISSN No. 2455-2143, Pages 119-126 \\ Published Online June 2020 in IJEAST (http://www.ijeast.com)}

\section{RECOMMENDATION}

Sweeping and cleaning of our environment is a continuous exercise and this assembly should be produced en-masse.

\section{Acknowledgement}

I am indebted to the Tertiary Education Trust Fund, The Federal Polytechnic, Ilaro and Abuja Offices (TETFUND) for awarding me a scholarship to support my academic pursuit. To my great and wonderful H.O.D, Engr. A, Dada- I deeply appreciate your mentoring and leadership roles. A big thank you toProf. Festus A. Oyawale of the Department of Mechanical Engineering, Covenant University, Ota, Ogun State.

\section{REFERENCES}

[1] Aluko, O. (2001) Environmental Pollution and Waste Management, Odus Prints, Ibadan, Oyo State.

[2] Adebesin, A.A (2017) Development and Performance Evaluation of a Street Sweeping Machine

Proceedings of the $2^{\text {nd }}$ International Conference of Engineering for a Sustainable World ICESW 2017 July 3-7, 2017, Ota, Nigeria

[3] Abu \& Elgaism (2011) Effect of Street Sweeping Methods: International journal of Science and Nature, 2 (3): 570- 574

[4] Ademosun, S.K (1990), Production Processing and Control, University Press, Ibadan

[5] Balague, F. Troussier, B. and Salminen, J. J (1999) Nonspecific low back pain in Children and
Adolescents: "Risk factors" European Spine Journal, 6 pp 429- 436

[6] Bridger, R.F. (1995) “ Introduction to Ergonomics" McGraw- Hill Inc. St. Louis.

[7] Daniel, A. B (1985): Production Fundamentals, Good Heart Willex Company. South Holland p20

[8] Das, A and Chakrabarti, D (2004):" Roles of Free Postural Adoption on Performance and Informal Workplace Design" Proceedings of National Conference on Humanizing Work and Work Environment, National Institute of Industrial Engineering, April, Mumbai.

[9] Harris, C., Straker, L., (2000), "Survey of Physical Ergonomics Issues Associated with School Children's use of Laptop Computers" International Journal of Industrial Ergonomic, Vol. 26 Issue 3 Pp 337-346

[10] Pheasant S, (1998); “ Body Space: Anthropometry, Ergonomics and the design of work" Second Edition, Taylor and Francis Press, London.

[11] Pheasant S, (1986); "Body Space: Anthropometry, Ergonomics and design" ,Taylor and Francis Press, Philadelphia, London.

[12] Troussier et al., (1994) "Comparative study of two different kinds of school furniture among children": Ergonomics, Vol. 42 No 3, pp 516526.

[13] Zacharkow, D; (1988) "Posture; Sitting, Chair Design and Exercise" Springfield, IL; CC

www.alibaba.com

Appendices

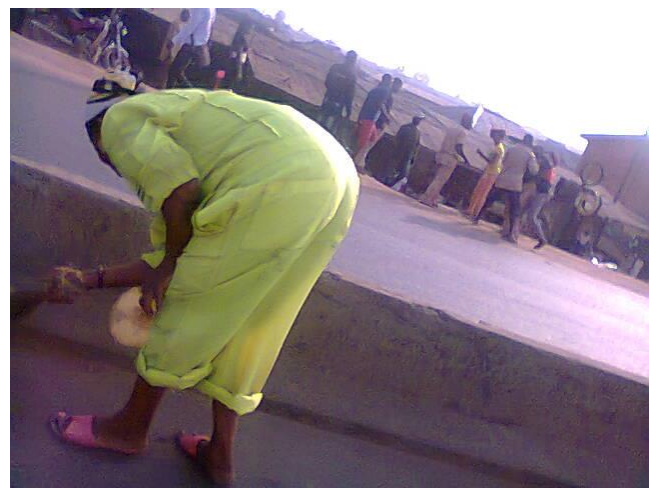

Plate 1: Picture taken along Sango/Covenant University route 


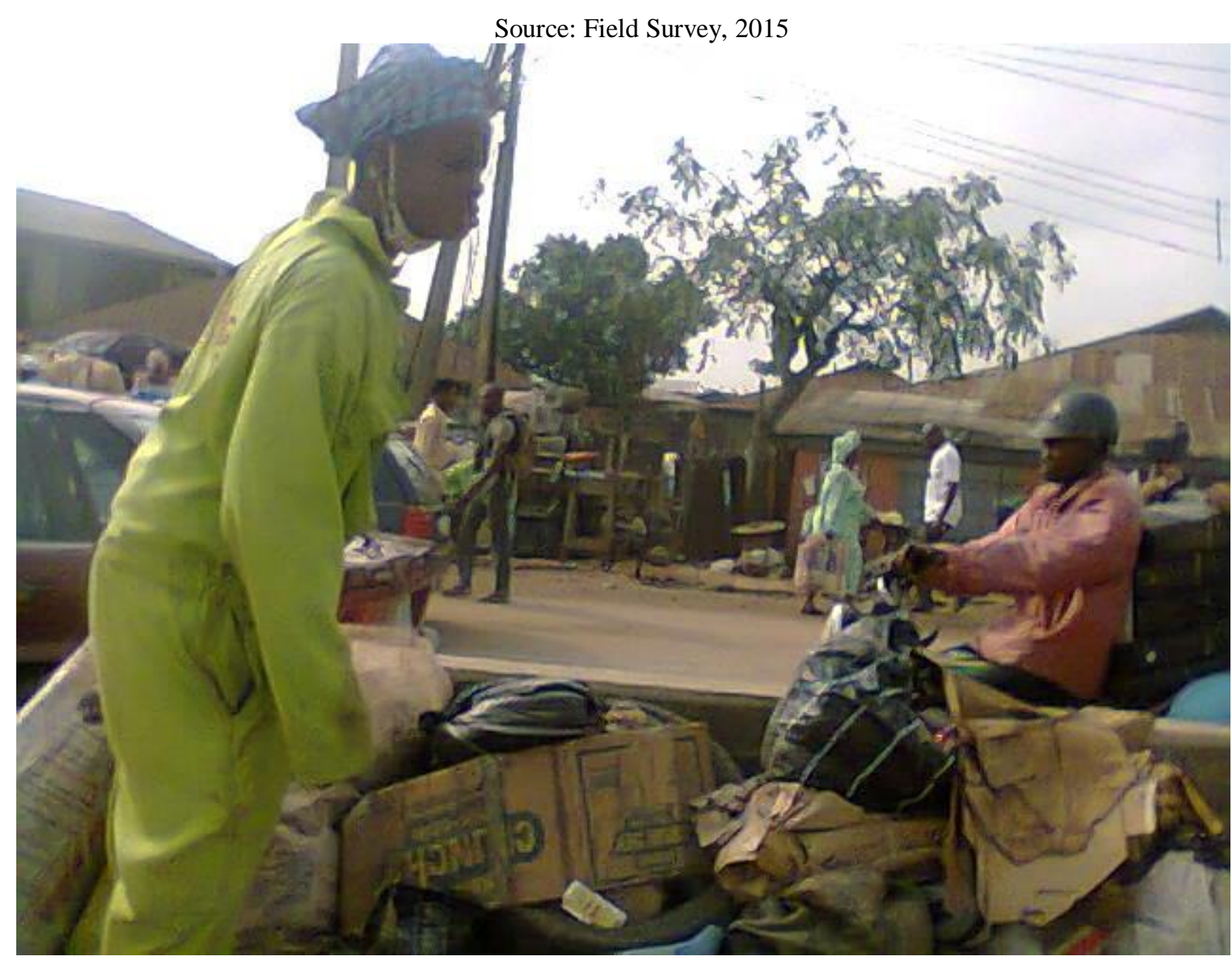

Plate 2: Picture taken along Sango/ Covenant University route Source: Field Survey, 2015 